\title{
TRAMAS DO DISCURSO, LUZES DA MEMÓRIA
}

\author{
Lucília Maria Sousa Romão
}

RESUMO: Le but de ce travail c'est d'étudier le discours sur le mouvement populaire de Canudos, lideré par Antônio Conselheiro, en 1893. Ce mouvement a commencé avec la fondation d'un petit village. Je vais comparer les sens mobilisés dans deux oeuvres: le livre-reportage de Euclides da Cunha, "Os Sertões", et l'oeuvre du voyaguer anglais, Robert C. Graham, "Um místico brasileiro - vida e milagres de Antônio Conselheiro". Je prétends faire cette analyse à la lumière de l'analyse du discours d'orientation française, qui affirme que le social est constitutif du langage. Cette théorie postule aussi un sujet interpellé par l'idéologie. Les concepts de position-sujet et inter-discours se présentent fondamentaux pour comprendre quels sont les sens qui retournent et quels sont les sens qui sont silenciés. Il est possible d'affirmer qu'il existe une région de l' interdiscours dans laquelle hier comme aujourd'hui les paysans politiquement organisés ont été diabolisés et criminalisés par le discours officiel, étant toujours presentés comme bandits, bande de voleurs, bagarreurs et illégaux.

PALAVRAS-CHAVE: Canudos, sujeito, sentido dominante, memória discursiva, criminalização do movimento popular, retórica do massacre, MST (Movimento dos Trabalhadores Rurais Sem Terra)

Lucília Maria Sousa Romão é professora da Universidade Estadual de São Paulo/Ribeirão Preto. 


\section{"Sertão. O senhor sabe: sertão é onde o pensamento da gente se forma mais forte que o poder do lugar." Guimarães Rosa}

Este artigo pretende apresentar o episódio de Canudos sob a perspectiva discursiva, interpretando uma região de sentidos da luta pela terra no país que tem sido solapada e silenciada. As acusações atribuídas aos canudenses (interpretadas a seguir) enredam um interdiscurso a partir do qual o camponês é visto como louco, visionário, fanático e criminoso. Marcada essa imagem e tecida tal representação, a memória discursiva ilumina e sombreia os relatos sobre os sem-terra de hoje, especialmente aqueles ditados pelo discurso jornalístico. Pelas tramas discursivas, luzes da memória se projetam e entram em cena, repertoriando efeitos de sentido de titânica depreciação daqueles que se mobilizam politicamente, na reivindicação e luta pela repartição da terra.

As questões teóricas propostas aqui são emolduradas pela Análise do Discurso de matriz francesa ( $\mathrm{AD}$, a partir de agora), que entende a linguagem como um terreno opaco de disputa e enfrentamentos entre sujeitos e sentidos, dados por uma conjuntura datada social e historicamente. Segundo (ORLANDI, 1996, p.151): “(...) há tensão entre interlocutores: tomar a palavra é um ato social com todas as implicações". Esse caráter tensional perpassa o discurso político de maneira exemplar, se tomadas a neutralidade e a isenção asséptica dos princípios da objetividade, transparência e exatidão como balelas ilusórias, já bastante desmistificadas pelos estudos da linguagem. Assim, é possível afirmar que as constelações de palavras polvilham o céu do dizer de imagens, desenhos, figuras, rotas e sentidos, que só podem ser entendidos a partir da amplitude do espaçomemória.

Em estudos anteriores, (ROMÃO, 2002) e (TFOUNI \& ROMÃO, 2003 a), interpretei alguns recortes que encaminharam a minha atenção para perceber o apagamento da luta política dos canudenses, silenciamento este cuja rosa dos ventos deletou a estufa social em que tal luta e reivindicação se engendraram. Ditos como fanáticos, loucos, religiosos dotados de toda sorte de cegueira, donos de uma vida passiva e contemplativa diante das explicações banais manipuladas por um líder salvacionista, os canudenses eram tidos como carne alucinatória a tumorizar a modernidade política trazida pela República. Narrados como pobres, miseráveis de horizonte e atrofiados pela vida sertaneja, dizia-se que imperava no Belo Monte um reduto, cuja geometria poderia ser traduzida pela falta de legitimidade religiosa, jurídica 
e social. É bom lembrar que o clero, os proprietários de terra, o establishment republicano e os intelectuais se postaram como que horrorizados diante das condições de vida, da religiosidade e da cultura própria do arraial. Melhor dizendo, nos quadris do sertão baiano, dançavam gritos descontentes e criaturas escaveiradas, que mereciam o apresamento e a eliminação de suas roças, construções, igrejas e vestígios. Não sem motivo, a cidadela do Belo Monte foi submersa pelas águas de um açude, na tentativa de afogar as memórias do território físico e das histórias contadas por ele, indicando a interdição de uma região de sentido.

A história amamentou a concepção descrita acima, até porque os registros oficiais, dados por jornalistas, escritores e representantes do Exército foram os únicos a serem publicados, sempre emoldurados pela conivência com o poder político de então e pela simpatia ao massacre.

"Para se escrever sobre guerra, é preciso entender de guerra. A lógica da imprensa de então foi esta. Euclides era tenente reformado. Outro enviado ao palco das operações, Júlio Procópio Favila Nunes, de A Gazeta de Notícias, era coronel. Manuel Benício, que fez uma boa cobertura jornalística para o Jornal do Commercio, e que no fim do conflito escrevia o livro O rei dos Jagunços, era capitão. Manuel de Figueiredo, da Notícia, tinha o posto de major. O tenente-coronel Siqueira de Menezes escrevia para O País usando pseudônimo. E mais: todo o material enviado era censurado previamente. Foi por isso que muita coisa sobre a guerra não foi publicada em jornal algum." (SOUZA, 2002, p.90)

Não é desse lugar que se produz hoje um acervo de estudos significativos a respeito. (CALASANS, 2000), (VILLA, 1999), (MOURA, 2000), dentre outros teóricos, têm contribuído para uma revisão de tal período, suturando a veia discursiva por onde escorre o sangue quente da indignação e clamor contra o latifúndio.

“Antônio Conselheiro, além de um ideário religioso, possuía também uma ideologia política e social (isso pode ser facilmente constatado em suas prédicas). Suas pregações iam ao encontro da expectativa de centenas de camponeses. Seu conhecimento teórico lhe possibilitava uma análise mais profunda das relações sociais existentes entre os trabalhadores, os fazendeiros e a questão da posse de terras, fator que inexistia em outros movimentos." (SOLA, 1997, p.20)

Na definição acima não se vê a imagem de louco ou fanático atribuída a Antônio Conselheiro, mas consolida-se a postura de um líder conhecedor dos mecanismos de exploração dos sertanejos, um engenheiro capaz de abrir o motor das relações sociais no campo, fazendo-o funcionar em outra direção. Também no trabalho de (MOURA, 2000, p.22), obser- 
va-se um movimento de revisitar Canudos sob o ponto-de-vista do seu valor político e social, como o processo final de uma longa trajetória de exploração, mobilização e resistência dos sertanejos.

"Canudos é um dos movimentos sociais mais importantes da América do Sul e culminou na maior guerra civil do Brasil, depois da Cabanagem no Pará e do Contestado em Santa Catarina. O seu conteúdo social e por isto também político não tem sido devidamente avaliado. A guerra liderada por Antônio Conselheiro é o reflexo eloqüente (...) das contradições que existiam naquela época e ainda persistem nas relações sociais do nosso setor agrário. Eclodiu em plena zona agropecuária dos grandes latifúndios do interior da Bahia e a violência dos combates travados entre os chamados fanáticos e as tropas do Exército bem refletem o grau de antagonismo a que haviam chegado as relações entre o latifúndio e a massa camponesa explorada da época."

Nas obras citadas acima e também em outros trabalhos que investiguei, dá-se corpo ao movimento de registrar o espaço trilhado por Conselheiro e por seus seguidores como um conjunto explosivo de recursos retóricos de reivindicação, táticas de defesa sofisticadas e produção alternativa auto-suficiente, capazes de tornar o arraial "um exemplo desafiador e perigoso". Isso porque:

"Canudos de simples fazenda que fora constituía agora um arraial (...) Transformara-se em ativo centro do comércio (...) 'os paióis continham provisão. As roças eram plantadas.' (...) Havia também atividade metalúrgica fabricando-se no arraial machados, facas, foices, para serem usadas nas atividades agrícolas e possivelmente militares. Fabricavam também a pólvora com o salitre local (...) Desenvolvia-se, assim, uma economia comunitária e alternativa auto-suficiente bem superior nas relações sociais e na distribuição da sua produção aquela baseada na exploração camponesa do resto da região. Daí o ódio e o temor dos fazendeiros e das autoridades ao seu crescimento e ao nome do seu líder Antônio Conselheiro.” (MOURA, op.cit., p.39-40)

Também em (MARTINS, 2001, p.120-121) o estudo sobre a economia do arraial contribui para entender a dimensão inovadora da produção local, indicando ser Canudos o grande casulo encubatório de uma economia solidária, baseada na cooperação e mutirão:

"Embora convencidos de que a economia da sociedade do VazaBarris foi muito pobre, como em geral o é a de quase todo o sertão brasileiro até os nossos dias, cremos que aquele povoado desenvolveu um sistema de produção primária capaz de proporcionar o auto-abastecimento e, ainda, algum excedente para o comércio externo, principalmente o de peles de caprinos." 
Observar Canudos dessa posição -utopia política e desenvolvimento econômico- oportuniza um gesto de leitura, que interpreta a cidadela do Bom Conselheiro como algo mais do que mulheres zoomorfizadas, homens armados e vidas medusadas pela religião e pobreza. Tal deslocamento conjuga-se com o princípio da $\mathrm{AD}$, que entende que o silenciado e o não-dito também reclamam interpretação.

“...partimos do dizer, de suas condições e da relação com a memória, com o saber discursivo para delinearmos as margens do não-dito que faz os contornos do dito significativamente (...) Entre o dizer e o não dizer desenrola-se todo um espaço de interpretação no qual o sujeito se move." (ORLANDI, 1999, p.83-85)

Portanto, para investigar o jogo de imagens e dizeres que entram em cena no embate sobre Canudos, me coloco no:

"lugar que enfrenta a pluralidade, o intervalar, a falta e o opaco como constitutivos da linguagem. No viés do que está escrito são bordados dizeres e silêncios grávidos de significação (...) $\mathrm{O}$ que o sujeito deixou de dizer ao dizer? O que silencia no dito? Qual o sentido latente no que falta dizer? Tais questões postam um olhar teórico e metodológico fecundo, pois assentam a análise no funcionamento do discurso, longe de categorias e regras pré-fixadas." (TFOUNI \& ROMÃO, 2003 b)

Rastrear os vestígios do que foi negado e apagado, no final do século XIX, nas chamadas lutas messiânicas (e no discurso sobre Canudos, especialmente) adensa a monumentalização da memória discursiva. Melhor dizendo, a partir do que foi soterrado e deletado sobre os canudenses, configura-se uma região de sentidos a ser lida e a funcionar como arquivo, produtora de imagens veiculadas sobre os sem-terra hoje. Esse processo é parte da memória discursiva, que sempre retorna, atualizando tanto os sentidos de reivindicação e luta pela terra (histórico de um movimento de resistência do sujeito) quanto os de criminalização dos camponeses (tentativa de apagamento e silenciamento da luta política e das mazelas sociais). Os defensores da reforma agrária e os interessados na manutenção do status quo do latifúndio significam (-se) se ancorados em zonas do já-dito. Canudos ontem e MST hoje que o digam.

"Sendo a memória discursiva constitutiva do sentido, há sempre várias vozes, historicamente constituídas, que voltam à tona, ressignificando certa formação discursiva. A amarração do discurso do sujeito com o discurso do outro indica a ideologia interpelando-o; tem-se aí uma dependência/ identificação/ associação a uma formação discursiva já dita. O sentido respira sempre atrelado ao interdiscurso." (ROMÃO, 2002, p.236) 
Entre escombros produzidos à cuspe de canhões, o reino perdido do arraial pode ser remontado no picadeiro da atualidade, se a miséria for entendida como característica que perfura os séculos e atravessa gerações de brasileiros. Nesse sentido, há uma simetria familiar entre as casas de taipa do arraial sertanejo e os barracos de plástico preto espalhados pelos acampamentos de hoje:

"Cem anos não se passaram e o paraíso da promiscuidade nos assedia em todos os pontos. Não se gastam mais um milhão e trezentos mil cartuchos, como na Quarta Expedição, para perfurar, com o progresso, quem nunca viveu tal palavra. Gastam-se bilhões para triturar miseráveis precoces e uniformizar a miséria nacional por quinhentos anos (...) E nosso leito histórico tem sido um Vaza-Barris de secas e carências, atrasos moderníssimos, sempre atualizados, para a grande maioria. Favelados já estão globalizados; mendigos são internacionais em qualquer metrópole e a nossa lei universaliza o desmando." (ARAÚJO, 2002, p.27-43)

Canudos desfiou um cancioneiro de penas, perdas, pesos, pés descalços de terra e caminhantes de esperança. Colocada a questão central que mobilizou índios, ex-escravos, pequenos produtores, artesãos, desempregados e excluídos -a luta contra a concentração de terra e de riquezaafirmo que a úlcera social da época consistia em graves desigualdades. Os miseráveis salpicavam os mandacarus como Quasímodos clonados pelo desemprego, abandono e fome. Discutir tais evidências da conjuntura social e política da época encerra um trabalho de desvelamento das condições de produção do discurso: “... o discursivo só pode ser concebido como um processo social cuja especificidade reside no tipo de materialidade de sua base, a saber, materialidade lingüística." (GADET \& HAK, 1997, p.179)

A partir desse momento, a conjugação das condições de produção e da materialidade lingüística irá compor o fio da interpretação usado nos recortes da centenária obra de Euclides da Cunha, "Os Sertões", cujo esboço fotográfico faz o percurso da terra, passando pelo homem até chegar à luta. Os trechos foram selecionados das duas últimas partes da obra e se seguem acompanhados da interpretação. Preocupa-me, sobremaneira, observar o funcionamento discursivo e a posição ocupada pelo sujeito desse discurso, além do movimento de afetação entre a língua e a história.

“...autoridade policial, por fim, apelou para os poderes constituídos, em ofício, onde, depois de historiar ligeiramente os antecedentes do agitador, disse: 'Nos dias de sermões, terços e ladainhas, o ajuntamento sobe a mil pessoas. Na construção desta capela, cuja féria semanal é de quase cem mil réis, décuplo do que devia ser pago, estão empregados cearenses, aos quais 
Antônio Conselheiro presta a mais cega proteção, tolerando e dissimulando os atentados que cometem, e êsse dinheiro sai dos crédulos e ignorantes, que, além de não trabalharem, vendem o pouco que possuem e até furtam para que não haja a menor falta, sem falar nas quantias arrecadadas que têm sido remetidas para outras obras..." (CUNHA, 1952, p.154)

As marcas acima encravam um poder garantido pelo suporte de leis, ofícios e documentos oficiais, que mobilizam um efeito de autorização para julgar, dizer e atuar com rigor. A autoridade policial-imperante na tarefa de controlar o cidadão e vozear o aparato repressor supostamente necessário à ordem -representa a contenção física como medida final de uma série de desobediências e infrações. A seqüência “... autoridade policial, por fim, apelou para os poderes constituídos" cristaliza a última possibilidade de tratamento da liderança Antônio Conselheiro: por fim, a prisão, o encarceramento vigiado pela polícia, como se outras tantas alternativas já tivessem sido executadas e como se não houvesse modo de suportar tal criminoso às soltas. A “mais cega proteção" de Antônio Conselheiro marca a incompetência individual para enxergar a realidade, deficiência visual incorrigível para a qual não existe cura nem lentes. Os óculos de submissão ao sistema inexistem. Ao cego, a escuridão. À mais "cega proteção", uma condenação penal contundente.

Há indícios, na ossatura da língua, que orientam essa zona de sentidos: "antecedentes" e "atentados" favorecem a construção do outro como grande infrator da lei, artífice de transgressões perigosas, escritor de ondas de crimes e violências sanguinárias. A reincidência na contravenção e a residência na ilegalidade: assim é dado o significado para o "agitador". É importante registrar que toda formação discursiva dá corpo a uma formação ideológica, que, nesse caso, generaliza o terror, o medo e a periculosidade dos canudenses, seres a malignar a paz sentenciada pela ordem social vigente. A naturalização desse e não de outro sentido indicia o lugar onde a ideologia está interpelando o sujeito.

O quadro de banditismo é associado a um boletim de ocorrência religioso: "sermões, ladainhas, capela, crédulos" contornam a conjugação entre o crime e a religião. A fé dos moradores, a execução de obras pias, as prédicas sacrossantas do Conselheiro e todas as práticas místicas vividas no arraial são apresentadas de modo a desnudar certa mutualidade entre dois esboços: o criminoso e o marginal da Igreja Católica clandestinizam uma dupla aberração. Enfim, os canudenses passam a ser rotulados como fora-da-lei dos homens e também como fora-da-lei de Deus.

O sujeito desse discurso desfibra a carne da luta política, de modo a se instalar na região do interdiscurso que concebe o grito contra a ordem 
vigente como estupor insubordinado, merecedor da necessária contenção e/ou eliminação. Vale destacar que tais sentidos já estavam postos naquilo que se dizia dos negros aquilombados: "rebeldes, agressivos e insolentes", os escravos, que não se submetiam ao açoite ou à senzala, eram narrados como infratores de modo semelhante, também criminalizados pela sílaba do seu desejo de liberdade.

As duas representações acima se adensam quando o sujeito registra que há "crédulos e ignorantes", "que além de não trabalharem, vendem o pouco que possuem e até furtam", ou seja, o canudense é sentenciado como vagabundo, ladrão, malfeitor e salteador, sem caráter nem religião de bons princípios, digno de ações perigosas e merecedor de uma sentença condenatória. Resta-lhe a paz do cemitério ou o mofo da detenção. Tais sentidos entram em erupção em várias passagens de "Os Sertões", dentre as quais destaco a seguinte:

"Canudos era o homizio de famigerados facínoras. Ali chegavam, de permeio com os matutos crédulos e vaqueiros iludidos, sinistros heróis da faca e da garrucha. E êstes foram logo os mais quistos daquele homem singular, os seus ajudantes de ordens prediletos, garantindo-lhe a autoridade inviolável. Eram, por um contraste natural, os seus melhores discípulos. A seita esdrúxula -caso de simbiose moral em que o belo ideal cristão surgia monstruoso dentre aberrações fetichistas- tinha os seus naturais representantes nos Batistas truculentos, capazes de carregar os bacamartes homicidas com as contas dos rosários (...) Inexorável para as pequenas cultas, nulíssima para os grandes atentados, a justiça era, como tudo o mais antinômica, no clã policiado por facínoras. Visava uma delinquiência especial, traduzindo-se na inversão completa do conceito de crime." (CUNHA, op.cit., p.170-171)

Nesse fragmento, destaco os significantes que se seguem: "facínoras, heróis da faca e da garrucha, famigerados, bacamartes homicidas, Batistas truculentos, facínoras, grandes atentados", pois eles mobilizam uma região de representações e imagens capazes de narrar Canudos a partir da tirania dos seus criminosos. Desse modo, parece que enxurram o arraial os mais célebres assassinos, homens perversos, bandidos assoberbados pelas habilidades da clandestinidade. Tal designação metralha as causas sociais que levaram os sertanejos a se mobilizarem, solapa a luta emancipatória pela terra e foca a questão na ilegalidade. Ao dizer que a questão do Belo Monte era de ordem judicial e penal, o sujeito deixou de dizer que o esgoto social evacuava enormes levas de seres humanos das mínimas condições de vida digna. Também aboliu do cenário discursivo oficial a possibilidade de ver a população honesta e trabalhadora do local, 
bem como enterrou as práticas produtivas do local. Alguns estudiosos ressaltam que tal designação não coincide com as práticas desenvolvidas por ela. (MARTINS, 2001, p.120) refuta tal visão:

“Não aceitamos a idéia de que o arraial sertanejo (...) vivesse de butins, saques e pilhagens perpetrados contra as populações vizinhas. Tal afirmativa, além de preconceituosa, pretende negar:

a) a eficácia do discurso do líder contra o pecado mortal do roubo, furto ou expropriação - discurso muito vivo, ainda hoje, no imaginário de sua gente;

b) o relato de diversos combatentes das forças oponentes sobre o encontro de pertences, inclusive monetários, à exceção de armas e munição, junto aos corpos sem vida de seus companhei$\operatorname{ros}(\ldots) "$

Ao dizer "homizio", o sujeito cria o efeito de generalização como se toda a população canudense vivesse no arraial para se esconder da vigilância da lei. Canudos é discursivizada como esconderijo, abrigo, refúgio e guarida para infratores, a etimologia desse vocábulo indicia um movimento nessa direção. Do arcaico, homizio deriva de homicídio + ar, o que significa o homicida que foge à ação da justiça e busca um lugar para escapar de uma punição legal. Tais pistas materializam um esboço do povoado como tendo somente homens ameaçadores. Silenciam-se o trabalho coletivo, a produção agrícola, o trato com os rebanhos de cabras, a lida com a metalurgia e até mesmo o fato de que a cadeia do arraial nunca tenha sido usada. Esse movimento impede o morador do Belo Monte de ser considerado um igual na ordem republicana, pois sabe-se muito bem que os direitos democráticos nesse período foram interditados a grande parcela da população, longe de serem distribuídos de maneira homogênea e igualitária. Ao contrário disso, eles sempre foram privilégio de quem deteve o poder das terras, das armas e da hóstia. Aos que nada possuem, até o direito de existir costuma ser negado... De tal modo que incriminar, imputar crimes, ter como bandido, dar-se como réu, acusar e condenar são verbos que interditam a expressão do outro, abafam o sentido de resistência e patenteiam aquilo que pode ser considerado a não legitimidade moral, religiosa e jurídica, não havendo outro eco que não a idéia da desordem e do caos. Assim, justifica-se o massacre.

$\mathrm{O}$ sujeito vai geometrizando o efeito de que a religião alimenta o crime e é alimentada por ele. Quanto mais religioso, mais bandido. Maior o crescimento da beataria, mais sofisticado o suporte que dá sustento ao banditismo. As duas seqüências: "Seita esdrúxula -caso de simbiose moral em que o belo ideal cristão surgia monstruoso dentre aberrações fetichistas" e "sinistros heróis da faca e da garrucha (...) eram (...) os seus melhores discípulos" pontilham o papel que o credo cumpre ao reforçar a 
transgressão e valorizar os mais sanguinários infratores. O tempo da condenação de Canudos roda num instante, de modo que se instala uma circularidade perversa: o arraial é a ponta final da violação dos estatutos jurídicos, já que representa o refúgio e esconderijo para onde os "famigerados facínoras" vêm, na mesma medida em que é o alimento e a nutrição para que novas violações da ordem jurídica aconteçam, gerando novos homicidas, agora com os terços atados às armas. Continuando meu passeio pelos sentidos instalados em "Os Sertões", dois trechos capturaram a minha atenção.

“... Ademais ninguém se iludia ante a situação sertaneja. Acima do desequilibrado que a dirigia estava tôda uma sociedade de retardatários. O ambiente moral dos sertões favorecia o contágio e o alastramento da nevrose. A desordem, local ainda, podia ser núcleo de uma conflagração em todo o interior do norte. De sorte que a intervenção federal exprimia o significado superior dos próprios princípios federativos: era a colaboração dos Estados numa questão que interessava não já à Bahia, mas ao país inteiro." (CUNHA, op.cit., p. 219)

"E Antônio Conselheiro -um Messias de feira- empolgara nas mãos trementes e frágeis os destinos de um povo... A República estava em perigo; era preciso salvar a República... Era este o grito dominante sôbre o abalo geral..." (CUNHA, op.cit., p.318)

Os recortes acima materializam marcas relacionadas à posição geográfica de Canudos: "situação sertaneja, ambiente moral dos sertões, local, interior do norte, Bahia, país inteiro”. Sem apear da crença positivista na qual se acomoda, razão um determinismo geográfico, o sujeito desse discurso promove uma associação entre a região nordeste (especialmente o sertão) e os efeitos de primitivismo e atraso, pespontando uma relação de causalidade entre eles. As regiões mais desconhecidas, longínquas e distantes do interior do país são abraseadas por todas as faltas, também aqui a etimologia do termo sertão aquilata o seguinte campo semântico: "Nos antigos mapas portugueses, 'Sertão', aumentativo de deserto, era o nome dado às terras desconhecidas, as quais se presumiam povoadas de prodígios estranhos e ameaçadores. Por extensão, uma metáfora do 'irracional' ." (LEMOS, 2002, p. 75)

Olhando os implícitos e pausas silenciadas nos dois fragmentos de "Os Sertões", observo a ideologia atuando de modo a sentenciar que os traços retardatários e desequilibrados do universo canudense compõem o cenário daqueles que se postam fora do compasso desenvolvido no litoral e nas cidades europeizadas, cujo bem-estar material combinava com a alta cúpula do clero e do poder político. O olhar que constrói o discurso sobre 
Canudos é, nesse sentido, estrangeiro, de alguém que vê o sertão do lado de fora, associando as condições geográficas e a secura do clima a um suposto atraso cultural, fanatismo, degenerescência genética do povo e disposição para a marginalidade. Ao registrar a situação sertaneja, o sujeito desse discurso coloca a cultura do sertão e a figura do sertanejo agigantados pelo estigma do obsoleto, antiquado, retrasado e distante, cuja drenagem para a civilização é o único meio de evitar o "contágio e alastramento da nevrose". É como se houvesse uma fila simbólica de avanços sociais, morais, religiosos e políticos, restando aos moradores do Belo Monte a última posição. Volto ao campo semântico dado pela palavra sertão, que empresta a essa formação discursiva uma memória na/da língua.

"A palavra sertão tem servido, em Portugal e no Brasil, para designar o 'incerto', o 'desconhecido', o 'longínquo', o 'interior', o 'inculto' (terras não cultivadas e de gente grosseira), numa perspectiva de oposição ao ponto de vista do observador, que se vê sempre no 'certo', no 'conhecido', no 'próximo', no 'litoral', no 'culto', isto é, num lugar privilegiado -na 'civilização'. É uma dessas palavras que traz em si, por dentro e por fora, as marcas do processo colonizador (...) Refletia na América o ponto de vista do europeu -era o seu dito (ou seu ditado), enquanto nas florestas, nos descampados, nas regiões tidas por inóspitas, de vegetação difícil, se ia criando a subversão de um não-dito nativista e sertanista." (TELES, 2002, p. 263)

Vale destacar que as características atribuídas ao sertão desdobram-se em uma gradação crescente, de modo a promover o deslocamento de um problema regional para todo país. O movimento metonímico de tomar uma parte de um território por uma nação mostra o riscado de uma cadeia destruidora. A sociedade de retardatários, exemplarmente fixada na região de Canudos, abre seus braços em direção ao "interior do norte" e compromete todo o país: a ameaça desloca-se do corpo da terra para o corpo do Estado. E, se o caos se estende em direção a outras regiões é porque existem "mãos trementes e frágeis" de um "Messias de feira" na coordenação do arraial. Há um paradoxo e eu me pergunto: como mãos tão fracas podem conduzir o estandarte de um movimento tão coeso politicamente? De que modo o demente ameaça? A conexidade das marcas "sertão-mãos frágeis-povo-perigo-abalo geral" cria um movimento de minimizar o valor da região sertaneja-líder-caos no país. O corpo tido como fraco e insano de Antônio Conselheiro, fruto de uma sociedade dita como atrasada, cria a situação descontrolada do perigo doentio do "contágio", o que coloca lado a lado efeitos desvalorização e depreciação. Da terra ao corpo do líder, retornando à pele do país: a andança do sujeito percorre um farto 
material simbólico de apagamento das violências sofridas pela população pobre do sertão como a promover a tropicalização do mal.

Ao destinar o outro ao lugar de todos os atrasos, o sujeito se insere no local do avanço. A "República, Estados, o país inteiro, princípios federativos, federal" metaforizam o simbólico que ordena e controla, a entidade superior da pátria e da lei, cuja supremacia deve ser tida como a representação de um ser superior. Grosso modo, a tarefa nacionalista impõe uma manobra retórica e militar civilizatória, cujo núcleo duro é eliminar do país as áreas gangrenadas pelo messianismo e pela politização dos excluídos. Mas, por que tal eliminação se tornou uma suposta necessidade nacional? A resposta parece simples, Canudos chegou a ser a segunda maior cidade da Bahia, contabilizando por baixo mais de 20 mil moradores (alguns estudiosos falam em 30 mil!), alavancou deslocamentos de massas de excluídos e impulsionou a distribuição igualitária da terra.

"Qualquer que tenha sido, entretanto, o tamanho da população que povoou a utopia conselheirista -12 mil, 20 mil, 24 mil, 30 mil, 35 mil ou mais almas-, o líder sertanejo idealizador e implementador do Belo Monte, sem qualquer favor, se incluiria na galeria dos administradores de cidades de porte médio, segundo os dados demográficos da época." (MARTINS, 2001, p.80)

Desse modo, observo que são emprestados da Biologia e da Medicina termos que retratam -outra vez- negativamente o arraial. O sujeito constrói o perigo de que o "ambiente do sertões favorecia o contágio e o alastramento da nevrose", de que "poderia ser núcleo de uma conflagração em todo o interior do norte". Vindas de uma outra zona do interdiscurso, que normalmente não é usada para explicar os fatos políticos, os termos se referem a doenças, epidemias, males físicos que acometem um número grande de pessoas e que podem fugir ao controle dos médicos, levando populações inteiras à morte ou abatimento. O desequilíbrio do sistema orgânico físico de uma pessoa é transferido para o desarranjo do regime republicano e do corpo nação. Em um movimento metonímico, o mal-estar crônico e irreversível de um pedaço do território passa a ser tomado como um quadro de proporções avassaladoras e doentias para todo o país. O pressuposto de que existia um diagnóstico médico confiável coloca em cena o remédio amargo a ser administrado ao paciente-Brasil: a eliminação daquela que seria a causa do contágio, ou seja, a destruição de Canudos.

Diante desse perigo assustador, a eutanásia do arraial, pela via de doses cavalares de cartuchos de metralhadoras, litros de querosene e balas de canhão, passa a ser sentenciada com a mesma autoridade de uma prescrição medicamentosa em um boletim médico. A "intervenção federal”, (inter- 
venção também cirúrgica, por que não?), realizada por tantos comandantes, prezava uma ação de força para "salvar a República". O sujeito coloca o regime republicano como capaz de debelar a infecção causada pelos conselheiristas, de controlar a febre do paciente e de extirpar os órgãos cancerosos para manter o corpo-nação em bom funcionamento. Por fim, submergir o cadáver para que dele não sobrasse nenhum sinal de anomalia.

Além dos sentidos já estudados até aqui: bandidagem, ilegalidade e ameaça contagiosa, outro indício merece atenção. $\mathrm{O}$ funcionamento discursivo do trecho a seguir cria o efeito de desumanização dos belomontenses.

"Chegavam, todavia, da zona das operações, telegramas paradoxais e deplorávelmente extravagantes. Calcavam-se numa norma única: - Bandidos encurralados! Vitória certa! Dentro de dous dias estará em nosso poder a cidadela de Canudos! Fanáticos visivelmente abatidos!" (CUNHA, op.cit., p.421)

Nesse recorte, me chama a atenção a designação "bandidos encurralados". O curral encrava bois na sua condição de contenção, aprisionamento e cerco. Da mesma forma, os canudenses são discursivizados como gado a ser contido para o abate, como animal a ser marcado pelo ferro em brasa das armas e pelas vogais dos clarins. A partícula "abatidos" guarda uma homonímia: tanto pode significar que os canudenses estavam cansados, enfraquecidos e diminuídos, como pode pontuar a morte deles. O acervo de sentidos derivados desse significante se abre em um jogo polissêmico, que entrelaça a condição de humilhado, prostrado, derrubado, derrotado: enfim, vencido. Em todos eles, o sentido oficial fixa uma única direção de leitura: qual gado, a condição dos habitantes é desumanizada. Entrelaçase, assim, certa composição de uma tela, cujas cores são o banditismo, o fanatismo e a irracionalidade. Sem a feição humana, fica mais evidente a necessidade da eliminação. Legitima-se, mais uma vez, a retórica do massacre, posto que ao animal indócil, selvagem e perigoso, restam as jaulas e as covas.

É interessante observar como tais sentidos retornam na obra do viajante londrino Robert B. Cunninghame Graham, que, tendo estado no Brasil por volta de 1914, re-escreveu a saga camponesa de Canudos. Publicada em 1920, a obra construiu uma narrativa engenhosa, ágil e densa, mostrando ao público europeu um capítulo da vida brasileira até então menosprezado e desconhecido. Escrito há pouco mais de duas décadas da extinção do arraial, o autor bebeu em fontes euclidianas. Preocupa-me a partir de agora interpretar o funcionamento da memória discursiva, o eterno ir-e-vir dos sentidos errantes, que transitam emprestados e tomados de formações discursivas já materializadas, já ditas, já-lá. 
No quadro teórico da $\mathrm{AD}$, o interdiscurso (ou memória discursiva) merece a seguinte conceituação: “(...) a memória funciona como espaço de legitimação, espaço este que atualiza e reorganiza o imaginário, tendo a linguagem como constitutiva de sentidos e identidades, e não como instrumento de expressão" (LUCAS, 2000, p.33). O lugar da memória é aquele que estabelece a condição de legibilidade do dizer, posto que as palavras não guardam um sentido em si mesmas, mas significam pela anterioridade, pelo arquivo que elas constituem (e que as constituem) e pelo movimento construído socialmente a partir da relação delas com o poder. Segundo (ORLANDI, 1990), usamos palavras que já têm sentido. Fazendo a topografia apurada desse pilar teórico, o trabalho de (MARIANI, 1998, p. 38) afirma que:

"A memória pode ser entendida como a reatualização de acontecimentos e práticas passadas em um momento presente, sob diferentes modos de textualização (...) na história de uma formação ou grupo social. O recordar possibilitado pela memória também se concretiza no movimento do presente em direção ao devir, engendrando assim uma espécie de 'memória do futuro’ tão imaginária e idealizada quanto a museificação do passado em determinadas circunstâncias."

Retomando o que já foi dito, podemos afirmar que pensar discursivamente a memória é analisar as formas conflituosas de inscrição da historicidade nos processos de significação da linguagem.

Portanto, a tarefa do analista é recolher os fios capilares dessa memória manifesta no intradiscurso tanto quanto possível, desenrolando o novelo imaginário de certo Teseu (perdido) na tentativa de uma saída-sentido para o labirinto-discurso. Tarefa dificultosa na lida com as bordas e opacidades de tais fios:

“... [a memória] não poderia ser concebida como uma esfera plena, cujas bordas seriam transcendentais históricas e cujo conteúdo seria um sentido homogêneo, acumulado ao modo de um reservatório: é necessariamente um espaço móvel de divisões, de disjunções, de deslocamentos e de retomadas, de conflitos, de regularizações... Um espaço de desdobramentos, réplicas, polêmicas e contra-discursos." (PÊCHEUX, 1999, p.56)

Na mesma direção, (COURTINE, 1981, p.49) destaca que as fronteiras de uma formação discursiva não apresentam rigidez, compondo membranas que re-editam e renegociam repetições e transformações de elementos: "L'interdiscours d'une FD, comme instance de formation/ répétition/ transformation des éléments du savoir de cette FD, peut être saisi comme ce qui régie le déplacement de ses frontières." 
Na sequiência, apresento o primeiro recorte da obra de (GRAHAM, 2002), cujo funcionamento discursivo será analisado a partir das noções de historicidade e memória, na tentativa de investigar o que e como retorna e quanto desliza para fixar o mesmo sentido já cristalizado e naturalizado.

"Os seguidores que o Conselheiro congregava eram os das classes que costumam congregar a princípio os profetas quando começam a pregar. Vaqueiros e remadores de canoas, pastores e pescadores, sempre os primeiros a acudir a um messias de qualquer tipo, acostumados à fé e à paciência, como os seguidores de qualquer chamado, constituíram seus primeiros convertidos ou sectários. Desclassificados, negros, esses habitantes da dupla Bohemia da pobreza e da cor, deixavam a caneca dos mendigos ou a gadanha no campo e engrossavam a multidão de fiéis, à qual se juntou o devido fermento de ladrões e desses homens que, nas regiões silvestres como o sertão, começam sua vida com um junta de bois que gradualmente produz um rebanho. Os homens que matam o gado de seus vizinhos protegidos pela escuridão e vendem couro com a marca distintiva recortada, chegaram em seus cavalos magros, mal-alimentados e indomáveis e formaram uma rústica guarda de cavalaria. Toda essa gente derrotada na luta pela vida, era precisamente a classe de homens que acodem a um profeta..." (GRAHAM, 2002, p. 92)

A designação dos "seguidores" de Antônio Conselheiro ganha um relevo especial na materialidade lingüística, já que o sujeito desse discurso busca defini-los, especificando o campo de atuação deles: "vaqueiros, remadores de canoas, pastores, pescadores", braçais ligados à lida no campo em tarefas e práticas de agricultura, pastoreio e pesca, cujo valor econômico e social passa a ser desmerecido pela condição de classe. Pertencem à série "das classes que costumam congregar a princípio os profetas quando começam a pregar" esboçados por um perfil generalizante. O valor, a cultura e os saberes da classe explorada, a falta do reconhecimento material e a carência de um salário justo, o próprio trabalho pesado são sentidos tangenciados. Em lugar disso, descreve-se uma classificação capaz de categorizar um "seguidor" como sendo pobre, mão-de-obra braçal e profissão de pouco valor. "Desclassificados, negros, esses habitantes da dupla Bohemia da pobreza e da cor" também corrobora para compor o mosaico adjetivado dos conselhereiristas: os sem-classe associam-se a uma etnia específica, como a formular certa equação de igualdade entre a cor da pele, a falta de educação, os traços do caráter. É possível perceber uma transferência em cadeia: trabalhador do campo-pobre-negro-desonesto. Os traços mais visíveis, aparentemente percebidos pela pele e pela profissão, são tingidos pelas marcas: "multidão de fiéis, à qual se juntou o devido 
fermento de ladrões". A bandidagem é aqui o adereço que faltava para compor o personagem digno de desvalia, isso porque a tatuagem da pobreza, negritude e do trabalho camponês recebem a coloração da ladroagem, banditismo, transgressão jurídica e torpeza.

A narração de feitos dos "seguidores do Conselheiro" passa por um boletim de ocorrência no estilo policialesco, quando o sujeito constitui (-se) na sequiência: "Os homens que matam o gado de seus vizinhos protegidos pela escuridão, vendem couro com a marca distintiva recortada". A especificidade dos crimes pode ser condensada em atos que estariam envolvendo roubo, ilegalidade e negócios ilícitos. Retornam, então, aqueles sentidos já postos na/pela formação discursiva dominante observada na obra "Os Sertões", cujo sujeito se movimenta em uma gangorra que criminaliza o arraial e deprecia as ações de seus moradores. Descrever o outro como bandido interdita a sua fala, nega a sua produção, obstacula a sua defesa e dá um fim simbólico a sua existência.

Por fim, existe uma sentença final, ao modo de uma conclusão definitiva, afirmando que: "Toda essa gente derrotada na labuta pela vida, era precisamente a classe de homens que acodem a um profeta". Ao dizer "derrotada", o sujeito se inscreve na zona do interdiscurso, a partir do qual a gente de Canudos é vista como extenuada, vencida e incompetente para a "luta pela vida". O abatimento, a entrega, o estrago, a prostração diante da existência honesta e bravamente lutadora passam a funcionar como o dito oficial sobre o povo e as atividades do arraial.

Como eu já disse, o que é silenciado e sonegado de (do) dizer também reclama interpretação, de modo que, ao afirmar que a gente é derrotada, o sujeito deixou de materializar a luta que ali se encerrou. Não disse que fundar a cidade, erguer a igreja, lavrar a terra, tratar dos rebanhos caprinos, captar água, fabricar a pólvora, construir as casas, montar a guarda do arraial, organizar o trabalho eram atividades de luta e resistência. Tampouco registrou que usar armas de defesa, pensar estratégias de guerrilha, escalar os grupos de trabalho, recolher os mortos e conclamar os vivos pudessem ser lidos como grande apego à vida. $\mathrm{O}$ sujeito aqui promove uma manobra de apagamento de uma região do dizer que lhe é interditado, corporificando aquilo que a ideologia lhe permite enunciar. Devo marcar que tal processo não é uma escolha livre e voluntária do sujeito do discurso, a interpelação ideológica é de natureza inconsciente.

Dando continuidade à análise, irei reproduzir alguns recortes da obra do viajante inglês, em cujo funcionamento discursivo há uma recuperação do já-lá.

"Seus seguidores quiseram defendê-lo, já que eram numerosos e estavam armados." (GRAHAM, op.cit., p.95) 
"Seus habitantes [de Canudos] eram uma população ociosa, armada até os dentes, cuja principal ocupação consistia em beber rum e fumar tabaco de produção caseira em longos cachimbos feitos de canas cortadas à margem do rio (...) Na extensão total da vasta e turbulenta região, todos andavam armados; todos eram cavaleiros natos, cada homem, em maior ou menor grau..." (GRAHAM, op.cit., p.113)

"[os que migravam para Canudos] Percorriam um caminho sinuoso, fatigando-se através de matas e passagens de montanhas, todos entoando hinos, armados até os dentes e muitos deles, montados nos cavalos pequenos e vigorosos da região, recolhendo forragem." (GRAHAM, op.cit., p.115)

"Sob esse regime religioso, os simples sertanejos tornaram-se os mais ferozes fanáticos e mereceram bem o nome de jagunços pelo qual eram conhecidos. Todos andavam armados até os dentes, prontos a cumprir o mandato de seu profeta ao menor sinal, a vida humana, nunca valorizada no sertão, tornouse ainda menos valiosa..." (GRAHAM, op.cit., p.119-120)

Ao observar tais dizeres, proponho as seguintes questões: o que retorna da memória discursiva sobre Canudos? Como são promovidos os deslizamentos de sentido para que o mesmo se enraíze e construa uma única maneira de dizer? Parece-me que, nos recortes selecionados acima, existe a cristalização de uma imagem fortemente condenatória dos canudenses, verdadeiro curtume de vozes difamadoras já ditas e esticadas pela memória. O movimento de fazer voltar a bandidagem e de tornar o outro um suposto marginal fora-da-lei é cicatriz antiga na pele do interdiscurso e edifica a estratégica retórica, que dá sustento ao uso da força bruta e legitima o massacre.

Repetindo a expressão "armado até os dentes", o sujeito caminha pelos subterrâneos da memória, gemendo nas moendas da paráfrase para se ancorar na região de sentidos que entretece a acusação do outro. Nessa marca, regressam os sentidos já materializados em outro lugar e se inscreve a historicidade, conceito aqui entendido como (ORLANDI, 1990, p.35) formula:

“A história está ligada a práticas e não ao tempo em si. Ela se organiza tendo como parâmetro as relações de poder e de sentidos, e não a cronologia: não é o tempo cronológico que organiza a história, mas as relações com o poder (a política). Assim, a relação da $\mathrm{AD}$ com o texto não é extrair o sentido, mas apreender a sua historicidade, o que significa se colocar no interior de uma relação de confronto de sentidos.

A relação com a história é dupla: o discurso é histórico porque se produz em condições determinadas e projeta-se no 'futuro', 
mas também é histórico porque cria tradição, passado, e influencia novos acontecimentos. Atua sobre a linguagem e opera no plano da ideologia, que não é assim mera percepção do mundo ou representação do real."

Para a AD, o sujeito se fixa em certa zona do dizer, constituída historicamente e circunstanciada por condições materiais, ou seja, por um contexto específico. Ele ocupa uma formação discursiva, em cujo funcionamento a ideologia direciona o que pode e deve ser dito. Dito de outra forma, "o complexo das formações discursivas, em seu conjunto, define o universo do 'dizível' e especifica, em suas diferenças, o limite do dizer para os sujeitos em suas distintas posições (remissíveis a diferentes FDs)." (ORLANDI, 1990, p.39)

Tendo colocado tal questão, destaco as seguintes marcas: "armados", "os dois bandos armaram como para uma batalha", "os sectários equipados com trabucos, espadas e navalhas, e se preparando para atacar", "população ociosa, armada até os dentes", " todos andavam armados", "todos entoando hinos, armados até os dentes", "todos andavam armados até os dentes", "homicidas e ladrões de gado, homens degradados do sertão", "todos levavam armas de vários tipos", "todos armados até os dentes", "todos estavam armados até os dentes com navalhas e rifles", "bandos errantes de bandidos, ladrões de gado". São pistas de que a população pacífica e honesta do país se tornou refém da bandidagem. Repetindo a marca de que os belomontenses viviam "armados" constrói-se o sentido de que o terrorismo imperava no quadril do Belo Monte, de que a ameaça à República exigia uma ação forte de eliminação do arraial. Ao narrar o perigo armamentista, promove-se uma socialização da criminalidade e um alardeio da transgressão potencial gerada no útero da mãe-Canudos. Assim, desenha-se uma Babel sertaneja, que ameaça o Estado de Direito com uma população fortemente "armada até os dentes". É curioso observar que existe uma inversão na ordem das coisas: os sertanejos passam a ser vistos como geradores da violência e causadores da violação em lugar de serem derivados dela. De pacientes do caos social, passam a ser tidos como agentes da desordem. De vítima, a gestor da desfaçatez.

"Dessa forma, homicidas e ladrões de gado, os homens degradados do sertão afluíam a Canudos e eram recebidos no rebanho (...) A flor e a nata da sem-vergonhice dos jagunços chegou a Canudos para formar sua guarda pessoal. Todos eles tinham a vida humana em preço muito baixo, porque tinham arriscado a própria centenas de vezes em empresas desesperadas. Todos eram bons cavaleiros, hábeis com o laço e a lança, e todos eram homens acostumados à faca, por tê-la usado mais de uma vez em feiras e romarias. Todos levavam armas de 
vários tipos e as usavam habilmente, e não havia entre eles um velhaco que não devesse uma ou duas vidas (...) Depois apareceu Pajeú, um rufião que tinha cometido inumeráveis crimes, mas um gênio nato para a luta na selva e a guerrilha". (GRAHAM, op.cit., p.123)

No recorte acima, há um retorno a uma região do interdiscurso muito apregoada em "Os Sertões", o sujeito enuncia a negação da racionalidade do canudense. Desloca-o para o lugar da anomalia do crime: "Dessa forma, homicidas e ladrões de gado, homens degradados do sertão afluíam a Canudos e eram recebidos no rebanho (...) A flor e a nata da semvergonhice dos jagunços chegou a Canudos para formar sua guarda pessoal". Vida humana sem valor, "em preço muito baixo", desfigurada pela falta de lucidez só pode se encaminhar para o impulso desmedido e impensado de matar e morrer. A banalização da violência e a relação dela com o cotidiano dos moradores do arraial constituem um campo semântico, cujo sentido é depreciar as condições de vida, produção, religiosidade e cultura sertanejas.

No significante "rebanho" ecoa a condição de "encurralado" conforme já apresentei, a mesma feição bovina, desumanizada e desfigurada de racionalidade a que é reduzido o povo do local funciona aqui de modo a promover a naturalização de um perfil animalesco para os moradores do arraial. O sujeito transita pelo interdiscurso e se filia à tradição dominante, aquela que iguala gente à situação de gado a ser abatido. Ali ancora-se e se aloja para significar. "Homicida, ladrões de gado, sem-vergonhice, hábeis com o laço e a lança, acostumados à faca" criam o efeito de predisposição para a "guerrilha". A vocação dos "homens degradados do sertão" não seria outra que não o uso de ferramentas rudes e primitivas e a promoção da barbárie.

\footnotetext{
"Aqui e ali havia homens e jovens dispersos e, agrupados perto da porta, estavam os líderes da temível guerrilha, todos armados até os dentes." (GRAHAM, op.cit., p.127)

"... todos estavam armados até os dentes com navalhas e rifles, com espadas e esporas para o gado com ponta de ferro." (GRAHAM, op.cit., p.132)

"Canudos foi o ponto de concentração dos bandos errantes de bandidos, ladrões de gado e miseráveis que durante anos haviam infestado todo o território, entre o rio São Francisco e o das Éguas -de fato, desde o Piauí até a província de Goiás. Esses homens, embora ladrões e na maioria dos casos assassinos, estavam fortemente tingidos pela religião (ou a superstição); a fama de pregação de Antônio Conselheiro, unida a sua oposição ao governo, atraiu-os como um imã de ferro e, é claro, acrescentou enormemente o seu poder." (GRAHAM, op.cit., p.141)
} 
Mais um movimento de renegociação dos sentidos já postos em outro lugar diz respeito à noção de doença e chaga nacionais, causadas pela bactéria da sociedade belmontense. "Canudos foi o ponto de concentração dos bandos errantes de bandidos, ladrões de gado e miseráveis que durante anos haviam infestado todo o território..." delineia a recuperação de uma zona do interdiscurso, que acusa a devastação dos princípios democráticos e civis nacionais por meio de um "contágio". Causar grandes estragos, proliferar a doença e assolar a plantação da paz social como praga: nesse lugar são colocadas a liderança e a população do arraial tal e qual eu já havia observado na formação discursiva na qual a obra euclidiana se inscreve.

"[citando um documento escrito pelas autoridades de Itapicuru a um chefe de polícia da Bahia] A capela custou cerca de cem mil réis e todos os trabalhadores são do Ceará. Como estes são seus paisanos, Antônio Conselheiro protege-os cegamente, permitindo-lhes cometer toda sorte de desordens contanto que sigam com seu trabalho. Tendo-se suscitado uma disputa entre os fanáticos e o pároco de Inhambuque, os dois bandos se armaram como para uma batalha e os pacíficos habitantes se aterrorizam ao ver os sectários equipados com trabucos, espadas e navalhas, e se preparando para atacar." (GRAHAM, op.cit., p.106)

Outra marca que chamou a minha atenção é: “... os dois bandos se armaram como para uma batalha e os pacíficos habitantes se aterrorizaram ao ver os sectários equipados com trabucos, espadas e navalhas, e se preparando para atacar." O verbo aterrorizar coloca em funcionamento a mesma formação ideológica, que outrora apontava o perigo dos atentados e do terror, cometidos pelos integrantes do Belo Monte. Materializa-se a mesma formação discursiva que endereça o arraial a região do pavor, coerção e ameaça terrível à vida humana. Há um contraponto entre os "pacíficos habitantes" e a população conselheirista, que propõe um confronto envolvendo medo, insegurança e instabilidade dos habitantes da região circunvizinha. Fato não de todo verdadeiro, já que grande parte da população vizinha comercializava com os canudenses, fazia ofertas e doações para o Bom Jesus Conselheiro e mantinha relações cordiais com as gentes do arraial. A memória discursiva sobre tais fatos cristaliza uma repetição, que de tanto ser falada e re-dita, edifica a naturalização de um único sentido, como se houvesse apenas uma maneira de o sujeito se referir, designar e falar. Nesse caso, o armamento e a vocação belicista da população, além do terrorismo explícito dos seus atos, compreendem uma memória na língua, entendida da seguinte maneira:

"Gostaríamos de ressaltar que não estamos falando da 'língua na memória' na perspectiva saussureana entendida como uma 
língua 'localizada' na memória (como memória de um indivíduo). Falamos sobre a memória 'na' língua, isto é, sobre o modo como os sentidos produzidos e sustentados histórica e socialmente, pela repetição, se encontram nisto que chamamos de língua. Nesta perspectiva, podemos compreender que o modo como uma sociedade, um povo, produz sentidos historicamente encontra-se marcado em sua linguagem, no modo como ele fala a 'sua' língua, ou melhor, a língua que lhe é dado falar por sua história." (PAYER, 2000)

$\mathrm{Na}$ tentativa escafandrista de mergulhar nessa matéria fundante de sentidos -o interdiscurso-, cuja materialidade é constituída a partir de uma memória na língua, coloco o analista na condição de quem recolhe rastros, pegadas e pistas daquilo que torna a significar de novo. Dito assim, volto os meus olhos para um dos fragmentos mais metafóricos que encontrei na obra do inglês estrangeiro sobre Canudos.

"Assim, uma vez mais, perdido no coração do sertão, estava montado o cenário para a velha contenda entre as forças representantes da lei e da ordem e o mundo antigo, em que cada homem era sua própria lei -o mundo dos mitos e dos prodígios, dos profetas e dos milagres. O velho e o novo estavam frente a frente diante de Canudos: um, selvagem e brutal, mas não envergonhado minimamente; outro, pintado com listras de descombinadas cores, onde o Progresso, a Humanidade e a Tolerância estavam escritos com grandes letras. De um lado, uma alcatéia de lobos e, de outro, um submarino carregado com torpedos e minas." (GRAHAM, op.cit., p.190)

O sujeito modela uma bipartição como a propor duas zonas polarizadas e impermeáveis de sentidos: de um lado a Lei (“o Estado, os princípios federativos") e de outro a selvageria ("mundo antigo, selvagem e brutal"). É preciso anotar que essa ordem de litígio discursivo, esse front de vozes entrincheiradas, já havia se manifestado no discurso euclidiano sobre Canudos. A memória apenas re-entranha e faz circular a imagem da "velha contenda entre as forças representantes da lei e da ordem e o mundo antigo, em que cada homem era sua própria lei”. Tal sentença resume o cerne ideológico, que propõe um divórcio jurídico, cujo funcionamento tenta inventariar as necessidades do país, centradas nos/por princípios de ordem e progresso. $\mathrm{O}$ aparato jurídico $\mathrm{X}$ a falta do estatuto legal; o novo $\mathrm{X}$ o primitivo; o mundo republicano europeizado $\mathrm{X}$ o sertão indomável e rude em seus atrasos: esse imaginário atravessa o discurso da época e se solidifica até os dias atuais. O placar sempre favorável ao primeiro time revela que o Estado de Direito, o novo e a modernidade vão ultimando os raios da difamação de modo a alimentar os sentidos de repulsa pelo arraial.

A valoração de um suposto desenvolvimento social e econômico, 
arquitetado pela civilização litorânea, regurgita uma série de marcas que lhe atribuem legitimidade: "lei, ordem, Progresso, Humanidade e Tolerância". O sujeito se filia à tradição do sentido dominante, cujo funcionamento vai torpedeando a força do Estado, a justificativa de sua ação e as suas características mais honrosas. Ao dizer isso, o sujeito deixou de registrar a brutalidade da ação militar, a violência sanguinária do Exército, as formas de tortura e o extermínio de milhares de pessoas com os requintes de sadismo que a degola e a gravata vermelha permitem supor. O sujeito omitiu também as causas dessa ação militar, ou seja, a manutenção do privilégio da terra, a sustentação da ordem latifundiária já fixada há anos, a continuidade de uma sociedade baseada no servilismo, em que a guia do trabalho é dada pela relação senhor-servo, quando não senhor-escravo. As violências impostas ao arraial podem ser lidas assim:

"A violência em Canudos pode ser percebida sob várias dimensões:

a) a profunda 'exclusão social', para usar de expressão atualmente em voga, dos habitantes da comunidade sertaneja liderada por Conselheiro: pobreza material absoluta, desapropriação da terra e demais meios de produção, essas são características básicas da multidão de vencidos de Canudos (...)

e) de outra parte, a civilização do litoral urbanizado, europeizado, branco e 'modernizador' constitui esse outro pólo do grande choque de culturas, esse processo cumulativo de enganos, preconceitos, medos e desejo de eliminação do inteiramente diverso: 'Incompreensível e bárbaro inimigo!'” (HARDMAN ,1997, p.59)

Voltando à interpretação do último recorte da obra de GRAHAM, também nele se constrói uma cadeia de silêncios e implícitos: "o poder da lei e da ordem" e a sede de "Ordem e Progresso" não aceitam que os pobres questionem as cangas que lhe são impostas por séculos de exploração, tampouco os donos da terra (e do capital) negociam sentidos de distribuição igualitária ou tolerância diante de experiências, que politicamente podem subverter a ordem vigente. Em contrapartida, o sujeito desse discurso encontra no "mundo antigo (...) o mundo dos mitos e prodígios, dos profetas e dos milagres, velho (...) selvagem e brutal" o fanatismo e a violência, desdobrados em peças condenatórias, como a entrelaçar o labirinto de cactos a um conjunto de Minotauros da seca.

O efeito de acusação, localizado nessa formação discursiva, professa a crendice, o profetismo e o tom milenarista como causas que teriam forçado o incêndio e a destruição daquele mundo "selvagem e brutal". As normas de conduta, de produção e de organização dos populares moradores do arraial são tratadas como preceitos religiosos, deslizando do campo 
político para a área da fé. Não constituem um acervo reconhecido como legítimo pelo Estado, então, o canudense é falado como um caricatural retrocesso, atrasado pela cegueira religiosa, fato este que impede que os sentidos dados pela ciência, república e modernidade sejam compreendidos. Como um seguidor míope, capaz apenas de versejar um hinário religioso, constrói-se uma outra depreciação: o sertanejo é incompetente para sobreviver aos novos tempos de República, não tem capacitação para conviver inserido no "mundo com letras grandes". Fora da lei, fora da fé, fora da competência: está armado o cenário imaginário para a condenação total daqueles que desobedeceram a ordem latifundiária do interior baiano.

Somente a naturalização desse sentido oficial, mantido como eu já disse com a ampla divulgação dos relatos simpáticos ao genocídio, poderia engessar uma região do interdiscurso de modo que se silenciasse alguns pontos do arraial. Em primeiro lugar, o poder do movimento popular capaz de superar o sertão (o ser tão sofrido), criando mecanismos de produção, defesa, luta e resistência em região ingrata. Sem recursos, sem a presença de programas sociais de inclusão desenvolvidos pelo Estado ou pela Igreja, com milhares de negros alforriados tão escravos da miséria quanto do açoite e com a multidão anônima de miseráveis que chegava ao Belo Monte todos os dias, o arraial merece ser lido, no mínimo, como uma cidade organizada no plano administrativo e político, auto-suficiente no aspecto econômico e disciplinada nas questões de conduta pessoal. Contornou-se justamente o contrário: a exposição da chaga esfomeada e pobre do norte e nordeste serviu como estandarte do preconceito, do determinismo geográfico e da explicação fatídica de que o homem daquela região tem mesmo uma natureza de bugre e selvagem. Não é trazida à tona a forte presença dos populares na execução de mudanças radicais naquele contexto sócio-histórico.

As metáforas construídas no texto de Robert Graham sinalizam pluralidade de sentidos, posto que para a $\mathrm{AD}$ o sentido não é sentido "na", mas sentido "para". Sem uma constituição dada aprioristicamente e longe da visão de que o autor fixa uma direção unívoca para o significante, o sentido é entendido como efeito entre interlocutores. O imaginário que circula em redor da sequiência "alcatéia de lobos" evoca a ferocidade como característica primeira desse animal. A marca "lobos" tem no interdiscurso, dado pelas fábulas, contos de fada, lendas e histórias, o componente assustador de ameaça à vida humana com traços destrutivos e traiçoeiros. O não adestramento e a não docilidade de tal bicho coloca-o como morador de regiões afastadas, montanhas desertas e nevadas bem como de matas inabitadas. Isso fixa o reconhecimento de um ser vivo, cuja domesticação é impossível e cuja convivência com o humano não se dá de modo ne- 
nhum. Transferindo tal representação para os canudenses, essa metáfora recupera sentidos de selvageria, vida primitiva, hábitos e crenças afastadas da convivência com a República. É certo que a memória dá suporte para a metáfora que parece inaugurar uma nova imagem, mas re-configura o velho, o mesmo, o parafrástico. "Alcatéia" dá a dimensão do volume de lobos: o coletivo funciona aí de modo a engordar o perigo, assinalando a presença de bandos de criminosos e quadrilha de malfeitores. Quadrilha essa que passa a espelhar a crueldade, ferocidade e animalidade perigosas à condição humana.

Em contraponto à metáfora da "alcatéia de lobos", vê-se outra região de sentidos marcada pela presença de um "submarino carregado de torpedos e minas". O indicador que me apreende, à primeira vista, é a máquina avançada, fruto da tecnologia, exemplar de um equipamento capaz de investigar e rastrear os subterrâneos do mar. Feito para enfrentar intempéries de clima e pressão, resistente frente ao movimento das águas, o submarino guarda, ainda, outras tantas propriedades (o sujeito sempre submerge no mar dos sentidos): é elemento estratégico de defesa, pode ser usado em confronto bélico-armamentista, caminha silencioso escondido pelo escuro das funduras sem luz, carrega munição explosiva e reserva-se o silêncio de atacar o inimigo sem alarde no desprevenido das horas.

Assim, configura-se a representação emblemática da República, cujo matraquear esboça o desenvolvimento baseado na força modernizante e no cientificismo inaugurado pelo positivismo da época. Maquinaria forte e capaz de caminhar seguramente passando pelos movimentos messiânicos e implodindo os focos de atraso do sertão. O sujeito, ao enunciar o "submarino carregado de torpedos e minas", cria um alinhamento imaginário, transferindo à máquina-Estado os atrativos de força, potência, superação tecnológica e preciosidade.

Torna-se mais intensa a potência do submarino por causa do aparato que ele carrega: o significante "minas" pode ser lido a partir da pluralidade de sentidos errantes que os constitui. Há uma homonímia que merece ser exposta: primeiramente pode significar a cavidade de pólvora usada para explodir o que está em cima, causando destruição. Também indica fonte de uma substância, minério ou material precioso e de larga utilidade para a sobrevivência humana. Pelo viés da metáfora, o sujeito atribui à República o poder de trazer à tona a eliminação do arraial. Destruir e submergir o reduto belomontense para tornear a paz do país: assim o sujeito, interpelado ideologicamente, direciona-se para o lugar que concebe a República qual uma máquina, capaz de caminhar forte e resistente em direção à eliminação do atraso, minando o messianismo, perfurando a superstição e, dessa forma, irrompendo o banditismo. Ao destruir o velho 
e o feroz, a República lança minas de explosivos com vistas à exploração das riquezas do país, da ordem e paz republicanas. Então, o Estado usa um aparato bélico com a justificativa de fazer brotar as riquezas em trânsito no/do país.

O confronto entre "alcatéia de lobos" e "submarino carregado de torpedos e minas" põe em rota de colisão campos semânticos tidos como inconciliáveis. O sertão e o litoral são postados como realidades de impraticável convivência. $\mathrm{O}$ último decreta a ilegalidade do primeiro e sua posterior extinção. A República sufoca e soterra o arraial como se o discurso da modernidade, apregoado por ela, pudesse ser estendido a todos os brasileiros de maneira igualitária e como se a desigualdade não fosse a medida daquele e dos próximos anos (os nossos que o digam).

Ao legitimar a supremacia do mundo branco, influenciado pela Europa e, em cujas entranhas cresciam os princípios da Ordem e Progresso, o sujeito do discurso dominante transita pela região do interdiscurso, a qual destina o camponês e o sertanejo ao lugar de inculto, selvagem, feroz e atrasado, além de fanático e violento. Tais sentidos circulam ainda hoje nos relatos jornalísticos, depoimentos de uderistas e até intelectuais quando se referem ao MST. Eles ocupam a posição discursiva que sinaliza ser o sem-terra de hoje o satã de uma nova Canudos, marcada pela ilegalidade e agressão aos direitos democráticos (dentre os quais, o direito de propriedade) e à ordem social vigente. Legitima-se que a pele dele seja queimada pela chama de todas as balas, pela frieza de todas as celas e pelo fogo de toda a difamação.

Nesse estudo, parti da investigação do funcionamento discursivo de obras expressivas sobre o episódio de Canudos para observar o retorno de alguns significantes e o campo semântico acionado por eles. Também tive interesse em observar a memória da/na língua, pontuando a equação dos sentidos naturalizados pelo discurso oficial. A sanha emalhada pelos dois relatos dita, edita e redita um processo de diabolização, que se sustenta a partir de um interdiscurso. A urdidura da memória é condição para a existência do dizer, tão ou mais fundante que o silêncio. O arquivo vai sustenizando composições e pautas supostamente adormecidas de modo a riçar os pêlos e a língua do sujeito. Das prédicas sertanejas sufocadas, ecoam vozes e gritos que hoje se fazem ouvir nos dizeres do MST para além da solidão e da servidão instaladas no campo. Campos-gerais, dias e dores (in) de fechos massacrados e discursos nascentes, riobaldos de silêncios, impossibilidades de rasgar as veredas do sertão e desejos de quentura, que coincidem com aquilo que Guimarães Rosa escreveu: "O sertão não tem janelas nem portas". As tramas do discurso e as luzes da memória também não. 


\section{BIBLIOGRAFIA}

ARAÚJO, Arturo Gouveia de. O homem de 20 de janeiro. In: FERNANDES, Rinaldo de (org). O clarim e a oração. São Paulo, Geração Editorial, 2002.

COURTINE, Jean Jacques. Analyse du discours politique. Paris, Larousse, Langages, n. 62, juin 1981.

CUNHA, Euclides da. Os sertões (Campanha de Canudos). Rio de Janeiro, Francisco Alves, 1952.

GADET, Françoise \& HAK, Tony. Por uma análise automática do discurso -uma introdução à obra de Michel Pêcheux. Campinas, Ed. da Unicamp, 1997.

GRAHAM, Robert Cunninghame. Um místico brasileiro, vida e milagres de Antônio Conselheiro. São Paulo, Sá Editora \& Ed. da Unesp, 2002.

HARDMAN, Francisco Foot. Tróia de taipa: de como Canudos queima aqui. In: JUNIOR, B. A. \& Alexandre, I. (org.). Canudos: palavra de Deus, sonho da terra. São Paulo, Boitempo Editorial e Ed. Senac, 1997.

LEMOS, Maria Alzira Brum. Os Sertões: modernidade e atualidade. In: FERNANDES, Rinaldo de (org). O clarim e a oração. São Paulo, Geração Editorial, 2002.

LUCAS, Clarinda Rodrigues. Leitura e interpretação em biblioteconomia. Campinas, Ed. da Unicamp, 2000.

MARIANI, Bethania. O PCB e a imprensa. Campinas, Ed. da Unicamp, Rio de Janeiro, Revan, 1998.

MARTINS, Paulo Emílio Matos. A reinvenção do sertão. São Paulo, FGV, 2001.

MOURA, Clóvis. Sociologia política da guerra camponesa de Canudos. São Paulo, Expressão Popular, 2000.

ORLANDI, Eni. Terra à vista-discurso do confronto velho e novo mundo. São Paulo, Cortez, Campinas, Ed. da Unicamp, 1990. . A linguagem e seu funcionamento. Campinas, Pontes, 1996.

. Análise de discurso: princípios e procedimentos. Campinas, Pontes, 1999.

PAYER, Maria Onice. Linguagens -as práticas discursivas como locus de investigação. Simpósio Memória social: narrativas, 2000.

PÊCHEUX, Michel. Papel da memória. In: ACHART, Pierre (org). Papel da memória. Campinas, Pontes, 1999. p.49-56

ROMÃO, Lucília Maria Sousa. O discurso do conflito materializado no MST: a ferida aberta na nação. Ribeirão Preto, Faculdade de Filosofia Ciências e Letras da Universidade de São Paulo, 2002. (Tese de doutorado) 
ROSA, Guimarães. Grande Sertão: Veredas. Rio de Janeiro, Nova Fronteira, 1984.

SOLA, José Antônio. Canudos: uma utopia no sertão. São Paulo, Contexto, 1997.

SOUZA, Percival de. Conselhos de Antonio. In: FERNANDES, Rinaldo de (org). O clarim e a oração. São Paulo, Geração Editorial, 2002.

TELES, Gilberto Mendonça. O lu(g)ar dos sertões. In: FERNANDES, Rinaldo de (org). O clarim e a oração. São Paulo, Geração Editorial, 2002.

TFOUNI, Leda Verdiani \& ROMÃO, Lucília Maria Sousa. O MST no discurso jornalístico: confronto de posições, 2003. (No prelo).

TFOUNI, Leda Verdiani \& ROMÃO, Lucília Maria Sousa. $O$ discurso sobre Canudos e a retórica do massacre, 2003. (Artigo submetido à apreciação para Revista Terra Livre- Associação dos Geógrafos do Brasil). 